\title{
EXPERIMENTAL LOAD-DRIFT RELATIONS OF CONCRETE BEAM REINFORCED AND CONFINED WITH HIGH-STRENGTH STEEL BARS UNDER REVERSED CYCLIC LOADING
}

\author{
Retno Anggraini ${ }^{1,2}$, Tavio $^{1 *}$, Gusti Putu Raka ${ }^{1}$, and Agustiar ${ }^{1,3}$ \\ ${ }^{1}$ Department of Civil Engineering, Institut Teknologi Sepuluh Nopember (ITS), Surabaya, Indonesia, e-mail: \\ tavio@its.ac.id*, gupura1950@gmail.com \\ ${ }^{2}$ Department of Civil Engineering, Faculty of Engineering, Brawijaya University, Malang, Indonesia, e-mail: \\ retnoang@ub.ac.id \\ ${ }^{3}$ Department of Civil Engineering, Muhammadiyah University at Aceh, Indonesia, e-mail: \\ ampenan70@gmail.com
}

Received Date: November 2, 2020; Revised Date: April 20, 2021; Acceptance Date: June 5, 2021

\begin{abstract}
High-strength steel bars have different characteristics from normal-strength steel bars. Thus, the use of high-strength steel bars still needs to be investigated further before it can be used confidently in concrete structures. In the design, a reinforced concrete beam should also have enough ductility besides its loading capacity. One of the indicators identifies that a structure has sufficient ductility is its ability to maintain the load steadily due to progressive deformation. This paper presents the test results of three reinforced concrete beams designed with concrete strength $\left(f_{c}^{\prime}\right)$ of $30 \mathrm{MPa}$. Two different yield strengths $\left(f_{y}\right)$ of longitudinal and transverse reinforcements were used, namely, 420 and $550 \mathrm{MPa}$. The cross-sectional dimensions of the beams were $200 \times 300 \mathrm{~mm}$ with a total span of $2000 \mathrm{~mm}$ and a rigid stub at the midspan. The beams were simply supported by double rollers at their tops and bottoms. These special supports were located at both ends of the beams. The load applied at the midspan of the beam through the rigid stub with the displacement control. The loading pattern protocol by the drift was set from 0 to 5.5 percent. Based on the test results, it can be seen that the beams with high-strength steel bars could achieve a higher load capacity than the beams with normal-strength steel bars. On the other hand, the beams with high-strength steel bars produced lower deflection than the beams with normal-strength steel bars. Furthermore, it can be concluded that all the beams could withstand the minimum required of 3.5 percent. None of the beams indicated brittle failures. All of the beams could survived until the end of the cycles at a drift of 5.5 percent. This condition indicates that the reinforced concrete beams with higher-strength reinforcement $\left(f_{y}\right.$ of $\left.550 \mathrm{MPa}\right)$ could also maintain their load capacities under large deformation beyond the first yielding of the longitudinal steel bars.
\end{abstract}

Keywords: Cyclic Load, Disaster Risk Reduction, Flexural Strength, High-Strength Steel, RC Beams

\section{Introduction}

Concrete building structures located in earthquake-prone regions have higher risk than others $[1,2]$. Earthquakes often claim many lives due to the collapse of the buildings. Besides, the consideration on internal forces such as bending moments, axial forces, shear forces, and torsion $[3,4]$, the design of building structures in earthquake-prone regions requires good and specific detailings of reinforcement as well as confinement such that the structures have 
sufficient ductilities [5,6]. These requirements result in high volumetric ratio of reinforcement that causes the congestion of reinforcement $[7,8]$. One of the possible solutions is to use the high-strength steel bars for both longitudinal and transverse steels. The use of high-strength steel bars as reinforcement in concrete has several advantages, namely reductions of required steels, labor costs, and most impotantly, the steel congestion in concrete [9-11].

Due to the need of higher-strength steel bars for concrete structures as explained above, the strength of steel bars continues to increase and this needs to be researched carefully before it can be used with confident in concrete structures. In ACI 318M-14 [12], the maximum yield strength of steel bar permitted for flexural design calculations of concrete members is $420 \mathrm{MPa}$ (Grade 60). Higher strength of steel bar that allowed to use for flexural design calculations of concrete members located in highly-seismic zones (assigned as SDC $\mathrm{D}, \mathrm{E}$, and F) have been produced by the local steel manufacturers such as Grade $80\left(f_{y}\right.$ of 550 $\mathrm{MPa})$, Grade 100 ( $f_{y}$ of $\left.690 \mathrm{MPa}\right)$, and Grade 120 ( $f_{y}$ of $\left.830 \mathrm{MPa}\right)$. Furthermore, the latest edition of ACI 318M-19 [13] already permits the use of steel bar with the yield strength up to $550 \mathrm{MPa}$ (Grade 80) for flexural design calculations of concrete members. ASTM A706/A706M-16 [14] also specifies the yield strengths of steel bars up to Grade 80 ( $f_{y}$ of $550 \mathrm{MPa}$ ), whereas ASTM A1035/A1035M-20 [15] specifies even higher yield strengths of steel bars of Grade 80 ( $f_{y}$ of $\left.550 \mathrm{MPa}\right)$, Grade $100\left(f_{y}\right.$ of $\left.690 \mathrm{MPa}\right)$, and Grade $120\left(f_{y}\right.$ of 830 $\mathrm{MPa})$. These new grades of steel bars have different chemical compositions from those specified in ASTM A615/A615M-20 [16] for Grades 40 to 100. They have distinct characteristics from steel bars of Grades 40 to 100 in ASTM A615/A615M-20 [16]. The most significant difference is in terms of mechanical properties which is reflected by the stress-strain relation. The stress-strain curves of Grade-100 and 120 steel bars do not show clear yield plateau [15]. They are different from steel bars with Grades 40 and 60 that shows the clear elastic, yield plateau, and plastic including strain hardening branches [16].

However, the development on the use of higher-strength steel bars in Indonesia is not as fast as in the developed countries, such as in USA and Japan. The steel bars produced by the local manufacturers in Indonesia has just reached up to Grade 100 ( $f_{y}$ of $690 \mathrm{MPa}$ ). However, for flexural design calculations of concrete members located in highly-seismic zones (assigned as SDC D, E, F), the maximum yield strength is still limited to $420 \mathrm{MPa}$ [17]. Up to present, the application of steel bars with yield strength $\left(f_{y}\right)$ of $550 \mathrm{MPa}$ (Grade 80) for concrete structures (assigned as SDC D, E, F) are still in doubt due to the Code limitation [17] and the lack of researches and studies on its application in reinforced concrete members such as concrete beams (flexure). ACI 318M-19 [13] states that several requirements must be satisfied. Some of these requirements are: 1) the target yield strength $\left(f_{y}\right)$ and the tensile strength $\left.\left(t_{s}\right) ; 2\right)$ the minimum elongation; and 3$)$ the minimum tensileyield strength ratio (1.25 percent). These requirements depend on the yield strength and diameter of the steel bars. Researches have been carried out to investigate these requirements which include the characteristics of stress-strain curves, the tensile-yield strength ratio, and the maximum elongation for several higher-strength steel bars. The results obtained indicate that higher-strength steel bars could still meet all these three requirements even though the values are not as high as the corresponding values of the normal-strength steel bars [18-20].

Several studies have investigated the possibilities of using these high-strength steel bars for several structural members. Among them are the investigations related to the flexural behavior, crack width due to bending moment, shear behavior, and drift capacity of the beams with high-strength steel bars [21-24]. 


\section{Research Significance}

Various provisions stipulate the application of steel bars for reinforced concrete members. They involve the requirements for the use of steel bars in concrete structures, namely ASTM A615/A615M-20 [16]. There are Grade 40 ( $f_{y}$ of $\left.280 \mathrm{MPa}\right)$, Grade 60 ( $f_{y}$ of $\left.420 \mathrm{MPa}\right)$, Grade $80\left(f_{y}\right.$ of $\left.550 \mathrm{MPa}\right)$, and Grade 100 ( $f_{y}$ of $690 \mathrm{MPa}$ ). In addition to ACI 318M-19 [13], there is also a design guide provided by the ACI, namely ACI ITG-6R-10 [25] that allows the use of steel bars with the specified yield strength, $f_{y}$, more than $420 \mathrm{MPa}$ (Grade 60). In the previous edition of ACI 318M [12], the specified yield strength of particularly longitudinal deformed steel bars allowed for flexural members such as beams is limited to $420 \mathrm{MPa}$ or the stress associated with the strain value of 0.0035 . Grade 60 steel bar has a minimum yield strength of $420 \mathrm{MPa}$ with a clear yield plateau in the stress-strain curve [16]. It also limits the specified yield strength, $f_{y}$, of deformed steel bar used for shear reinforcement to 420 MPa (Grade 60) [12], which is in the latest edition of ACI 318M increased to $550 \mathrm{MPa}$ (Grade 80) [13]. However, ACI ITG-6R-10 [25] allows the use of specified yield strength, $f_{y}$, up to a maximum of $690 \mathrm{MPa}$ as concrete confinement only (ties or spiral). ACI 318M19 [3] specifies the maximum values of $f_{y}$ or $f_{y t}$ of steel bars permitted for design calculations according to the usage and application of the steel reinforcement in concrete members. Table 1 shows the limitations of yield strengths of steel bars for certain usage and application in concrete members [13].

Table 1. Maximum Yield Strength of Steel Bar According to Its Usage and Application [13]

\begin{tabular}{|c|c|c|}
\hline Usage & Application & $\begin{array}{c}\text { Maximum value of } f_{y} \\
\text { or } f_{y t} \text { permitted for } \\
\text { design calculations, } \\
\mathrm{MPa}\end{array}$ \\
\hline \multirow{6}{*}{$\begin{array}{c}\text { Flexure; axial force; and } \\
\text { shrinkage and } \\
\text { temperature } \\
\text { Lateral support of } \\
\text { longitudinal bars; or } \\
\text { concrete confinement }\end{array}$} & Special moment frames & 550 \\
\hline & Special structural walls & 690 \\
\hline & Other & 690 \\
\hline & Special seismic systems & 690 \\
\hline & Spirals & 690 \\
\hline & Other & 550 \\
\hline \multirow{5}{*}{ Shear } & Special moment frames & 550 \\
\hline & Special structural walls & 690 \\
\hline & Spirals & 420 \\
\hline & Shear friction & 420 \\
\hline & Stirrups, ties, hoops & $\begin{array}{l}420 \\
550\end{array}$ \\
\hline Torsion & Longitudinal and transverse & 420 \\
\hline \multirow{2}{*}{ Anchor reinforcement } & Special seismic systems & 550 \\
\hline & Other & 550 \\
\hline \multirow{2}{*}{$\begin{array}{l}\text { Regions designed using } \\
\text { strut-and-tie method }\end{array}$} & Longitudinal ties & 550 \\
\hline & Other & 420 \\
\hline
\end{tabular}

Some of the efforts to improve the ductility of concrete structures, among others, are by providing sufficient confinement to the structural members, and also by using steel bars for longitudinal reinforcement which provide adequately long elongation. The previous studies were conducted on either normal-strength concrete (NSC) or high-strength concrete 
(HSC) with several variations in the yield strengths of steel bars. They show that the concrete confinement can increase both strength and ductility of the concrete members. Several previous researches have already proposed the relationships for predicting the stress-strain behaviors of the confined concrete and the increases in strength and deformation/ductility [26-31].

The use of higher-strength steel bars for the design of both longitudinal and transverse reinforcements in the highly-seismic regions is permitted by the Code [13]. However, it must satisfy several requirements. One of the requirements is the minimum value of tensile-yield strength ratio of at least 1.25 percent [13]. Tavio et al. [19] have researched various strengths of steel bars ( $f_{y}$ of 550,650, and $700 \mathrm{MPa}$ ) produced by a local steel manufacturer and some of them have been used in construction. It shows that most of the high-strength steel bars used were still hard to attain the required tensile-yield strength ratio. Thus, in this research, a new product of steel bars particularly for Grade 80 steel bars were engineered and manufactured by a local steel company to meet all of the code requirements especially the tensile-yield strength ratio.

The drift ratio can be defined as the damage and ductility indicators of structural members. Ductility is a capability of a structural member to maintain its strength and capacity under deformation in the post peak response. There are several ductility parameters used to evaluate the behavior of reinforced concrete members. Among these parameters are the curvature ductility factor $\left(\mu_{\phi}\right)$, the displacement ductility factor $\left(\mu_{\Delta}\right)$, and the lateral drift ratio $(\delta)[32]$.

In the structural design, a building structure must be able to withstand a reverse cyclic loading as a representation of the actual earthquake load. The concrete beams with high-strength steel bars of Grade 97 ( $f_{y}$ of $670 \mathrm{MPa}$ ) had similar flexural and almost stable deformation capacities as those of beams with normal-strength steel bars of Grade 60 ( $f_{y}$ of $415 \mathrm{MPa})$. They also experienced quite slow degradation in the hysteretic curves up to the drift of 5 percent. All these conditions show the possibility of introducing the applications of high-strength steel bars as longitudinal reinforcement in concrete beams part of seismicresistant structures [33]. The ductility of a structural member is governed mainly by its stiffness stability in post-peak response. Considerable degradation in stiffness of a structural member under reversed cyclic loading occurs particularly after the steel bars start to yield $[33,34]$.

In the paper, a research on concrete beams reinforced and confined with higherstrength steel bars under reversed cyclic loading is reported. The application of higherstrength steel bars is to provide higher flexural beam capacity which is nowadays required as an alternative solution for longer beam span with very strict dimensional limitation due to the architectural demand. This research confirms that concrete beams reinforced and confined with higher-strength steel bars could also perform comparable ductile flexural behavior as those reinforced and confined with normal-strength steel bars. They also did not experience any brittle failures similar to those obtained in monotonic loading [35].

\section{Methodology}

In the study, three beam specimens were tested under cyclically reverse loading with a setup similar to the previous study [32]. The tests were carried out by applying the reverse cyclic load (push and pull loads) on the beam stub shown in Figure 1. The test beam specimens were simply-supported at both ends (Figures 1 and 2). The dimensions and properties of the test beam specimens are given in Figure 2 and Table 2. 


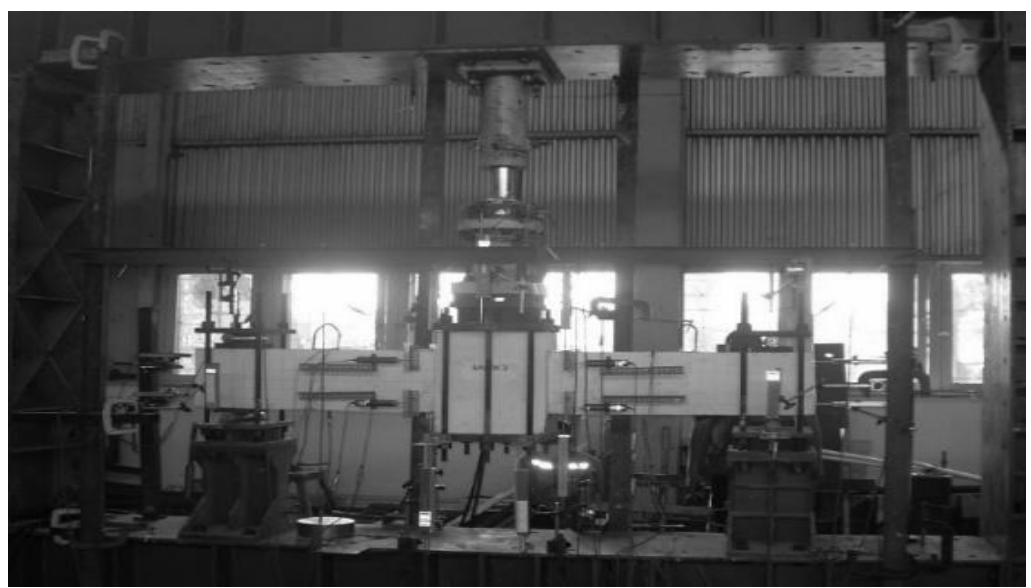

Figure 1. Photograph of test setup of a beam specimen

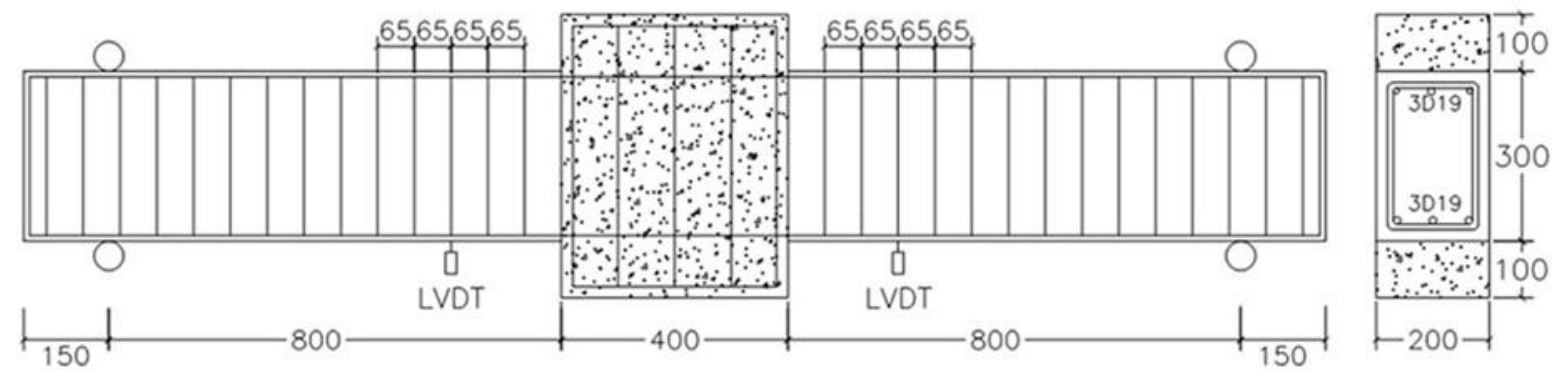

Note: all dimensions are in $\mathrm{mm}$

Figure 2. The dimension and setup of the beam specimen

Table 2. Concrete and Steel Bars Used for Test Beam Specimens

\begin{tabular}{cccccc}
\hline & Concrete & \multicolumn{2}{c}{ Longitudinal Steel } & \multicolumn{2}{c}{ Transverse Steel } \\
\cline { 2 - 6 } Beam ID & $f_{c^{\prime}}$ & $\begin{array}{c}f_{y} \\
(\mathrm{MPa})\end{array}$ & $\begin{array}{c}\text { Diameter } \\
(\mathrm{MPa})\end{array}$ & $\begin{array}{c}f_{y} \\
(\mathrm{MPa})\end{array}$ & $\begin{array}{c}\text { Diameter } \\
(\mathrm{mm})\end{array}$ \\
\hline $\mathrm{C} 1$ & 30 & 420 & $19(\mathrm{D} 19)$ & 420 & $10(\mathrm{D} 10)$ \\
$\mathrm{C} 2$ & 30 & 550 & $19(\mathrm{D} 19)$ & 420 & $10(\mathrm{D} 10)$ \\
$\mathrm{C} 3$ & 30 & 550 & $19(\mathrm{D} 19)$ & 550 & $10(\mathrm{D} 10)$ \\
\hline
\end{tabular}

All the test beam specimens in the study were designed with the same concrete strength, namely $f_{c}^{\prime}$ of $30 \mathrm{MPa}$. Meanwhile, for steel bars, two types of reinforcement were used, i.e. longitudinal and transverse reinforcements. Each reinforcement used two different yield strengths, namely $f_{y}$ of 420 and $550 \mathrm{MPa}$. The bar diameters used for longitudinal and transverse steels were 19 and $10 \mathrm{~mm}$ (D19 and D10 in which "D" indicates "Deformed", while "19" or "10" indicates "bar diameter" in $\mathrm{mm}$ ), respectively. Table 2 lists the variables of concrete and steel bars used for the test beam specimens. The test beam specimens were designed with the cross-sectional dimensions of $200 \times 300 \mathrm{~mm}$ and a total span of $2300 \mathrm{~mm}$. At the beam midspan, there was a stub with the dimensions of $400 \times 400 \times 300 \mathrm{~mm}$. The 
dimensions and properties of the beams were selected to follow those reported in the previous study [35]. For longitudinal reinforcement, three steel bars of D19 were used for each top and bottom side of the beam. For transverse reinforcement, they were distributed uniformly with a spacing of $65 \mathrm{~mm}$ along the beam spans at both sides of the stub.

The experimental tests carried out on the beam specimens were using the reversed cyclic loading. The load was performed using an actuator equipped with a load cell at the end of the stroke ram. The load cell was used to measure the applied load. The deflections or deformations of the beam were also measured using the LVDTs installed next to both faces of the stub and under the load. The data obtained included the progressive load and deformation or deflection of the beams until their maximum and final conditions of testing. The beam test setup and the instrumentation can be seen in Figures 1 and 2 .

The loading method used in the study was a quasi-static reversed cyclic loading. The loading protocol follows the ACI 374.1-05 [36] which requires every loading step to undergo three cycles. The drift ratio was used as a control parameter for loading instead of the force. According to ACI 374.1-05 [36], a drift ratio of at least 3.5 percent must be satisfied subjected to several requirements to ensure that the structural members such as beams or columns can be assigned as a part of a special moment frames (SDC D, E, and F/highly-seismic zone). The loading-pattern protocol according to ACI 374.1-05 is given in Figure 3. Each test beam specimen was subjected to a reversed cyclic loading using actuator installed vertically and mounted with the beam stub as can be seen in Figure 1. Each specimen experienced at least 11 cycles of incremental drift-controlled ratios following the loading-pattern protocol [36]. The drift ratios were set to increase step by step from 0 to 5.5 percent, i.e. $0,0.2,0.25,0.5,0.8,1.0,1.4,1.75,2.2,2.8,3.5,4.5$, and 5.5 percent. The end of testing depends on the resistance of the beam in maintaining the load. The drift ratio is the vertical displacement/deflection measured at the center of the beam stub divided by halfspan of the beam as shown in Figure 4.

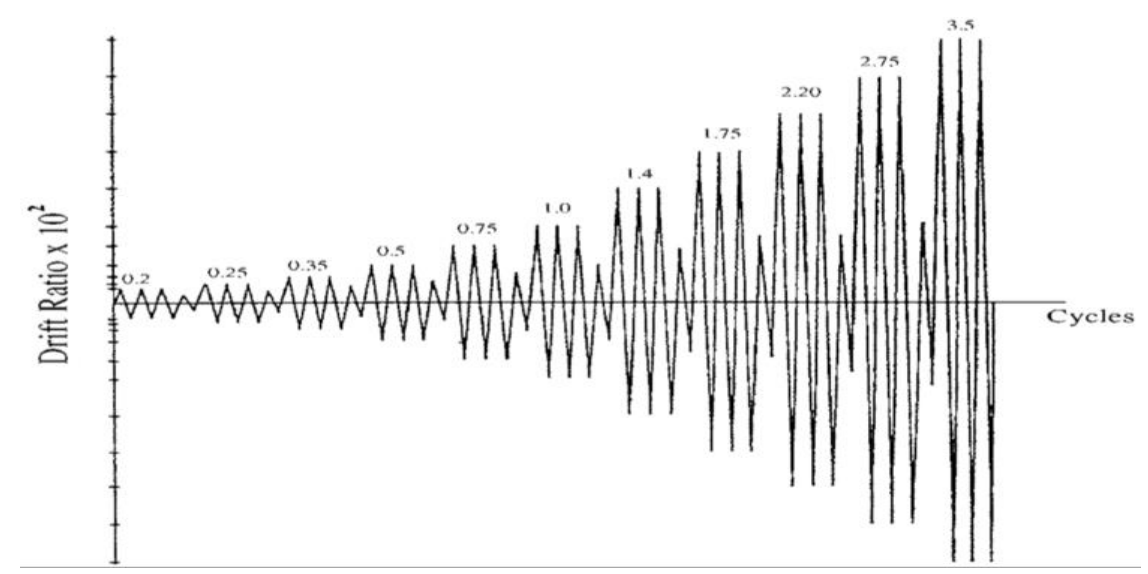

Figure 3. Loading-pattern protocol according to ACI 374.1-05 [36]

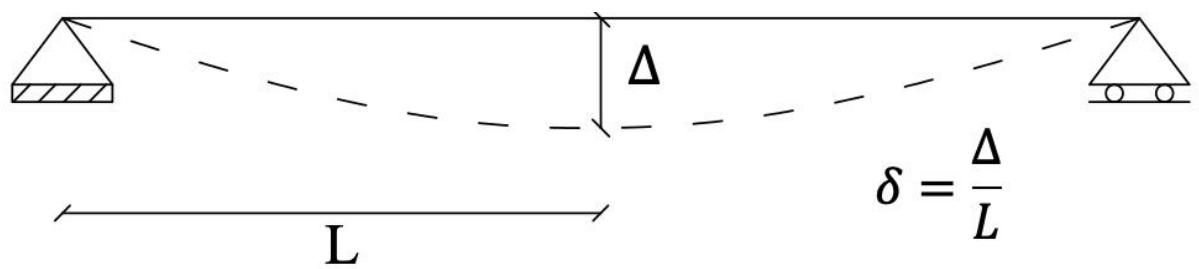

Figure 4. The drift ratio $(\delta)$ of the beam 


\section{Experimental Results and Discussion}

Testing of concrete strength was carried out in the study. Based on the concrete cylinder test results, the average concrete strength $\left(f_{c r}\right)$ at 28 days of age attained approximately $37 \mathrm{MPa}$. Figure 5 depicts the stress-strain curves of the steel bars used in the test beam specimens. Steel bars with the specified yield strength $\left(f_{y}\right)$ of $420 \mathrm{MPa}$ had the average yield strengths $\left(f_{y}\right)$ of about 437.9 and $466.7 \mathrm{MPa}$ for D10 and D19, respectively. Meanwhile, steel bars with the specified yield strength $\left(f_{y}\right)$ of $550 \mathrm{MPa}$ had the average yield strengths $\left(f_{y}\right)$ of approximately 546.3 and 583.4 MPa for D10 and D19, respectively. The tensile test results of steel bars are given in Table 3. From Table 3, it can be seen that all the steel bars used has satisfied the minimum elongation of 14 and 12 percent for Grade 60 ( $f_{y}$ of $420 \mathrm{MPa}$ ) and Grade 80 ( $f_{y}$ of $\left.550 \mathrm{MPa}\right)$, respectively, and the minimum tensile/yield strength ratio of 1.25 $[14,15]$.

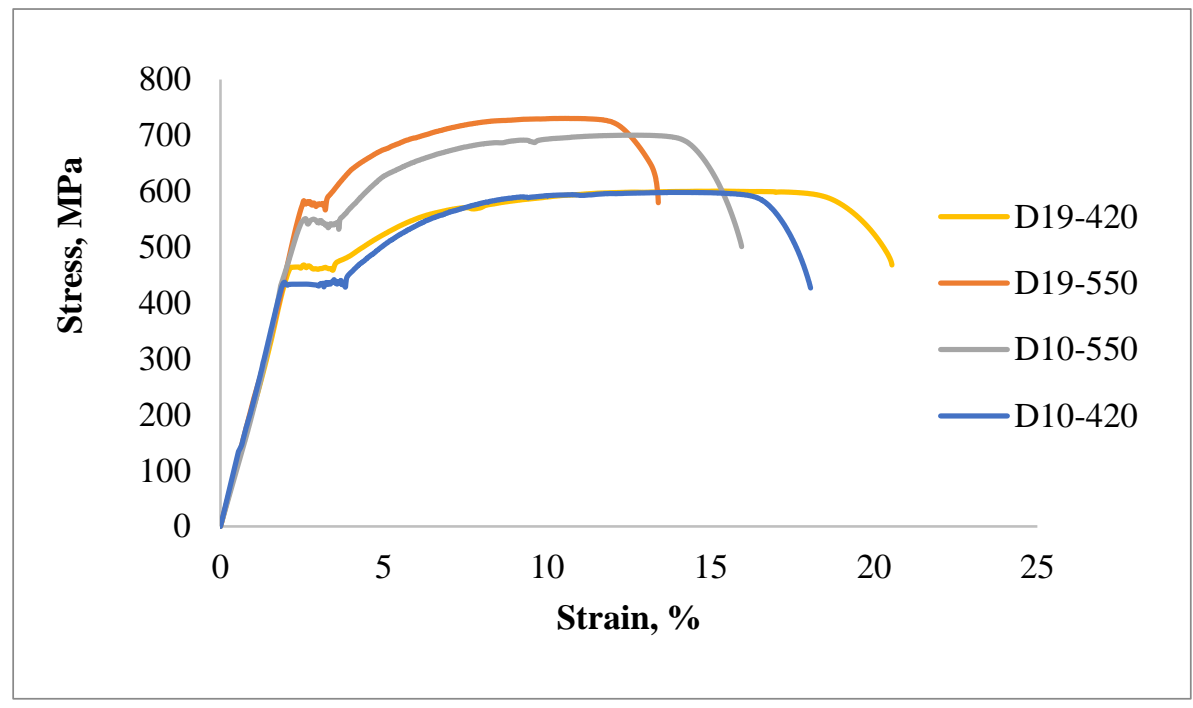

Figure 5. Stress-strain curves of steel bars used in the test beam specimens

The experimental test results include the load and displacement/deflection readings of each step and cycle of the test beam specimens. Table 4 shows the evaluation of the maximum loads and the corresponding drift ratios which is obtained from the displacements/deflections at the maximum loads (Figure 4). The maximum load is used to predict the value of the ultimate load which can be computed using the formula, $P_{u}=0.8 P_{\max }$.

Table 3. Mechanical Properties of Steel Bars Used in Test Beam Specimens

\begin{tabular}{cccccc}
\hline $\begin{array}{c}\text { Diameter } \\
(\mathrm{mm})\end{array}$ & $\begin{array}{c}\text { Speficied } \\
\text { Yield } \\
\text { Strength } \\
(\mathrm{MPa})\end{array}$ & $\begin{array}{c}\text { Average } \\
\text { Yield } \\
\text { Strength } \\
(\mathrm{MPa})\end{array}$ & $\begin{array}{c}\text { Tensile } \\
\text { Strength } \\
(\mathrm{MPa})\end{array}$ & $\begin{array}{c}\text { TS/YS } \\
\text { Ratio }\end{array}$ & $\begin{array}{c}\text { Elongation } \\
(\%)\end{array}$ \\
\hline $10(\mathrm{D} 10)$ & 420 & 437.9 & 586.6 & 1.34 & 17.2 \\
$19(\mathrm{D} 19)$ & 420 & 466.7 & 600.4 & 1.29 & 20.6 \\
$10(\mathrm{D} 10)$ & 550 & 546.3 & 685.7 & 1.26 & 16.9 \\
$19(\mathrm{D} 19)$ & 550 & 583.4 & 730.8 & 1.25 & 13.4 \\
\hline
\end{tabular}


Table 4. Load and Drift Ratio at Maximum and Ultimate States

\begin{tabular}{ccccccccc}
\hline $\begin{array}{c}\text { Beam } \\
\text { ID }\end{array}$ & $\begin{array}{c}P_{\max }^{(+)} \\
(\mathrm{kN})\end{array}$ & $\begin{array}{c}\text { Drift } \\
\text { Ratio at } \\
P_{\max }^{(+)} \\
(\%)\end{array}$ & $\begin{array}{c}P_{\max }^{(-)} \\
(\mathrm{kN})\end{array}$ & $\begin{array}{c}\text { Drift } \\
\text { Ratio at } \\
P_{\max }^{(-)} \\
(\%)\end{array}$ & $\begin{array}{c}P_{u^{(+)}}^{(\mathrm{kN})} \\
\mathrm{C} 1\end{array}$ & $\begin{array}{c}\text { Drift } \\
\text { Ratio } \\
\text { at } P_{u^{(+)}} \\
(\%)\end{array}$ & $\begin{array}{c}P_{u}^{(-)} \\
(\mathrm{kN})\end{array}$ & $\begin{array}{c}\text { Drift } \\
\text { Ratio } \\
\text { at } P_{u^{(-)}} \\
(\%)\end{array}$ \\
\hline $\mathrm{C} 2$ & 338.1 & 2.8 & 238.9 & 2.8 & 190.4 & 4.5 & 191.1 & 4.5 \\
$\mathrm{C} 3$ & 311.3 & 3.5 & 300.8 & 3.5 & 249.0 & 5.0 & 240.6 & 4.7 \\
\hline
\end{tabular}

Based on Table 4, it can be seen that beams with higher-strength steel bars ( $\mathrm{C} 2$ and $\mathrm{C} 3$ ) have the ability to carry higher loads than the control beam (C1). It shows that the use of higher-strength steel bars successfully confirms to increase the load capacities of the beams ( $\mathrm{C} 2$ and $\mathrm{C} 3$ ). Also, the drift ratio of Beams $\mathrm{C} 2$ at ultimate load is comparable to that of Beam $\mathrm{C} 1$. These findings suggest that beams with higher-strength of steel bars as longitudinal reinforcement can be used with confident instead of those with normal-strength steel bars (Grade 60). The use of higher-strength steel bars for transverse steel does not increase the load capacity of Beam C3 compared to Beam C2, but it certainly improves the drift ratio of Beam $\mathrm{C} 3$ when compared to Beam $\mathrm{C} 2$. This also indicates that the use of higherstrength steel bars as transverse reinforcement in concrete beams can improve the drift ratio which represents the ductility of the beam.

Table 4 shows that Beams $\mathrm{C} 2$ and $\mathrm{C} 3$ reach the highest maximum loads compared to Beam $\mathrm{C} 1$. This is because Beams $\mathrm{C} 2$ and $\mathrm{C} 3$ were designed with high-strength steel bars $\left(f_{y}\right.$ of $\left.550 \mathrm{MPa}\right)$ for their longitudinal reinforcements. The maximum push (+) and pull (-) loadings on Beam $\mathrm{C} 2$ occurred at Cycle 11 with the drift ratio of 3.5 percent. Beam $\mathrm{C} 1$ as the control beam was designed with the same reinforcement diameters but with different yield strength of steel bars $\left(f_{y}\right.$ of $\left.420 \mathrm{MPa}\right)$. This beam achieved lower maximum load than Beam C2.

The maximum push (+) load of Beam $\mathrm{Cl}$ occurred at Cycle 10 with the drift ratio of 2.8 percent, while the maximum pull (-) load occurred at the same cycle and drift ratio. Beam C3 which was designed with the same grade of longitudinal reinforcement (Grade 80 or $f_{y}$ of $550 \mathrm{MPa}$ ) and higher grade of transverse reinforcement (Grade 80 or $f_{y}$ of $550 \mathrm{MPa}$ ) than Beam $\mathrm{C} 2$ could achieve a comparable maximum load. The maximum push $(+)$ and pull $(-)$ loads of Beam C3 occurred at the same cycle and drift ratio (Cycle 11 and drift ratio of 3.5 percent, respectively). Table 4 also provides the ultimate loads and their corresponding drift ratios. From Table 4, Beams C1 and C2 experienced the ultimate load at Cycle 12 with the drift ratio of 4.5 percent, whereas Beam C3 experienced the ultimate load at Cycle 13 with the drift ratio of 5.0 percent. It can be seen that the ultimate state of Beam C3 occurred at later cycle than Beams $\mathrm{C} 1$ and $\mathrm{C} 2$. This is because Beam $\mathrm{C} 3$ was reinforced with higherstrength steel bars for transverse reinforcement than Beams $\mathrm{C} 1$ and $\mathrm{C} 2$. Thus, the drift ratio of Beam C3 was greater than those of Beams C1 and C2.

For the effect of transverse reinforcement in terms of flexural capacity, it can be concluded that there is almost no contribution. This is indicated by Beam $\mathrm{C} 3$ which could attain a maximum load of about 3.2 percent slightly greater than that of Beam $\mathrm{C} 2$ under push (+) load. However, Beam C3 could only reach a maximum load of about 1.7 percent slgithly lower than that of Beam $\mathrm{C} 2$ under pull (-) load. This is due to the difference between these two beams only on the yield strengths of their transverse reinforcements. 
The application of reversed cyclic loading to the beam can be reflected by the hysteretic curve from the response of each beam. Figure 6 shows a hystereric curves drawn from the load-drift ratio measurements at the beam stubs. Data readings include loads and displacements/ deflections that occur in the upper and lower stubs of the beams. From Figure 6 , it can also be seen that all the beams could sustain the required drift ratio of 3.5 percent. Furthermore, all the beams could survive without experiencing any sudden collapse up to a drift ratio of 5.5 percent. This findings confirm that the use of higherstrength steel bars for concrete reinforcement particularly for longitudinal steel is highly recommended.

The measurements of loads and displacements/deflections were not only taken at the beam stub, but also at the beams adjacent to the faces of the stub. The loads that occur at each cycle can be related to their corresponding drift ratios. The relationship between load and drift ratio (obtained from the measured displacement/deflection) can be represented by the hysteretic curve. To simplify, a backbone curve can be developed in lieu of the complete hysteretic curve shown in Figure 6. From the figure, it can be seen that all the test beams can sustain the drift ratio greater than 3.5 percent. Even though all the beams were tested to the drift ratio of 5.5 percent, they could only achieved the drift ratio of less than 5.5 percent when evaluated under the ultimate load, $P_{u}$ (taken as $0.8 P_{\max }$ ).

Table 5 shows that Beam C1-left can withstand the drift ratio of more than 3.5 percent. The readings of the lefthand and righthand faces of the stub of Beam $\mathrm{C} 1$ are not equal. The lefthand side of Beam $\mathrm{C} 1$ reached about 4.3 and 6.6 percent drift ratios at the push (+) and pull (-) loads, respectively; whereas the righthand side of the beam reached about 4.5 and 4.8 percent drift ratios at the push (+) and pull (-) loads, respectively. Beams $\mathrm{C} 2$ and $\mathrm{C} 3$ indicate almost similar results between the left and righthand sides of the beams. The righthand side of Beam $\mathrm{C} 2$ reached 5.0 and 7.1 percent drift ratios at the push (+) and pull (-) loads, respectively; while the lefthand side of the beam reached about 4.8 and 6.1 percent drift ratios at the push (+) and pull (-) loads, respectively. The righthand side of Beam C3 reached about 4.8 and 6.5 percent drift ratios at the push $(+)$ and pull $(-)$ loads, respectively, while the lefthand side of the beam reached about 5.0 and 5.8 percent drift ratios at the push $(+)$ and pull $(-)$ loads, respectively. These indicate that all the test beams could satisfy the drift requirement. In addition, there was no beam experienced any brittle or sudden collapse.

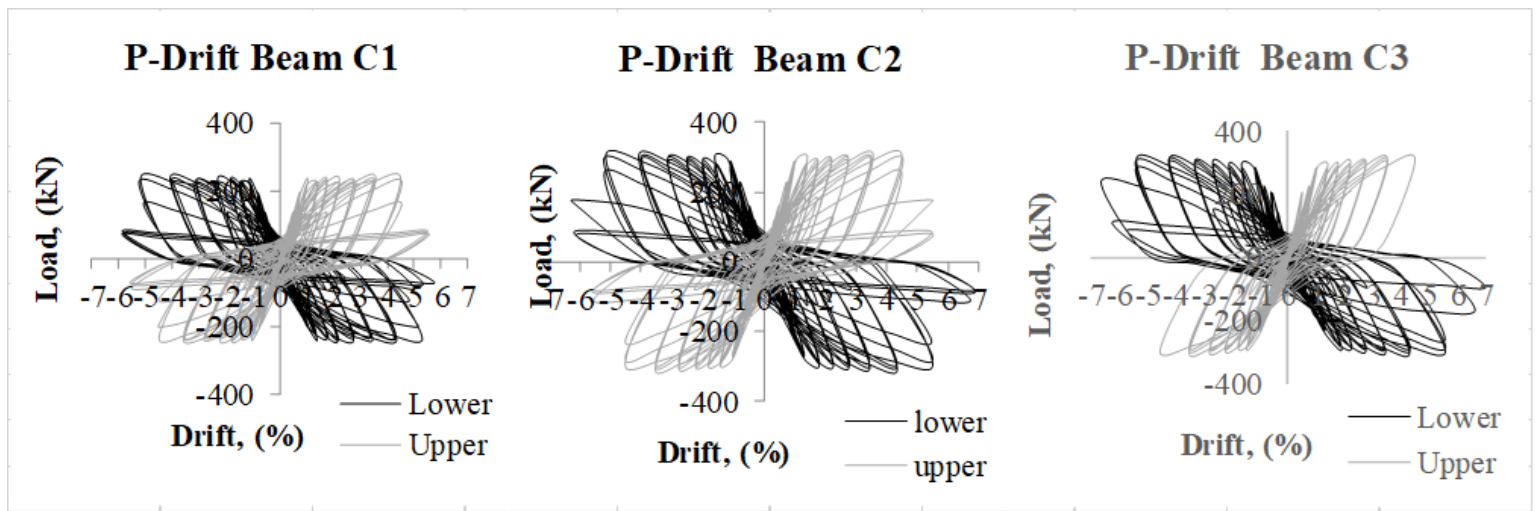

(a)

(b)

(c)

Figure 6. Hysteretic curves of the beam stubs: (a) Beam C1, (b) Beam C2, and (c) Beam C3 
Table 5. Drift Ratios at Ultimate Loads of Stubs and Beams

\begin{tabular}{ccccccc}
\hline \multirow{2}{*}{ Beam ID } & $\begin{array}{c}\text { Drift Ratio at Stub } \\
(\%)\end{array}$ & $\begin{array}{c}\text { Drift Ratio at } \\
\text { Righthand Side of } \\
\text { Beam } \\
(\%)\end{array}$ & $\begin{array}{c}\text { Drift Ratio at Lefthand } \\
\text { Side of Beam } \\
(\%)\end{array}$ \\
\cline { 2 - 7 } C1 & 4.5 & 4.5 & 4.5 & 4.8 & 4.3 & 6.6 \\
C2 & 4.5 & 4.6 & 5.0 & 7.1 & 4.8 & 6.1 \\
C3 & 5.0 & 4.8 & 4.8 & 6.5 & 5.0 & 5.8 \\
\hline
\end{tabular}

The hysteretic curves were also observed on the lefthand and righthand sides of the beams shown in Figure 7. These hysteretic curves show the relationships between the loads and the drift ratios of the beams during reversed cyclic loading. Each loading cycle was repeated three times. The deflection measurement of Beam $\mathrm{C} 1$ could not be cannot be carried out completely especially for the lower LVDT at the lefthand side of the beam due to its malfuction. It could only measure up to Cycle 7. However, for other beams (C2 and C3), the measurement could be completed until the end of all cycles.

From each cycle, the relationship between the load and its corresponding drift ratio can be simplified by taking only each peak point. These relationships are then presented in the form of the backbones of P-Drift curves as shown in Figure 8.
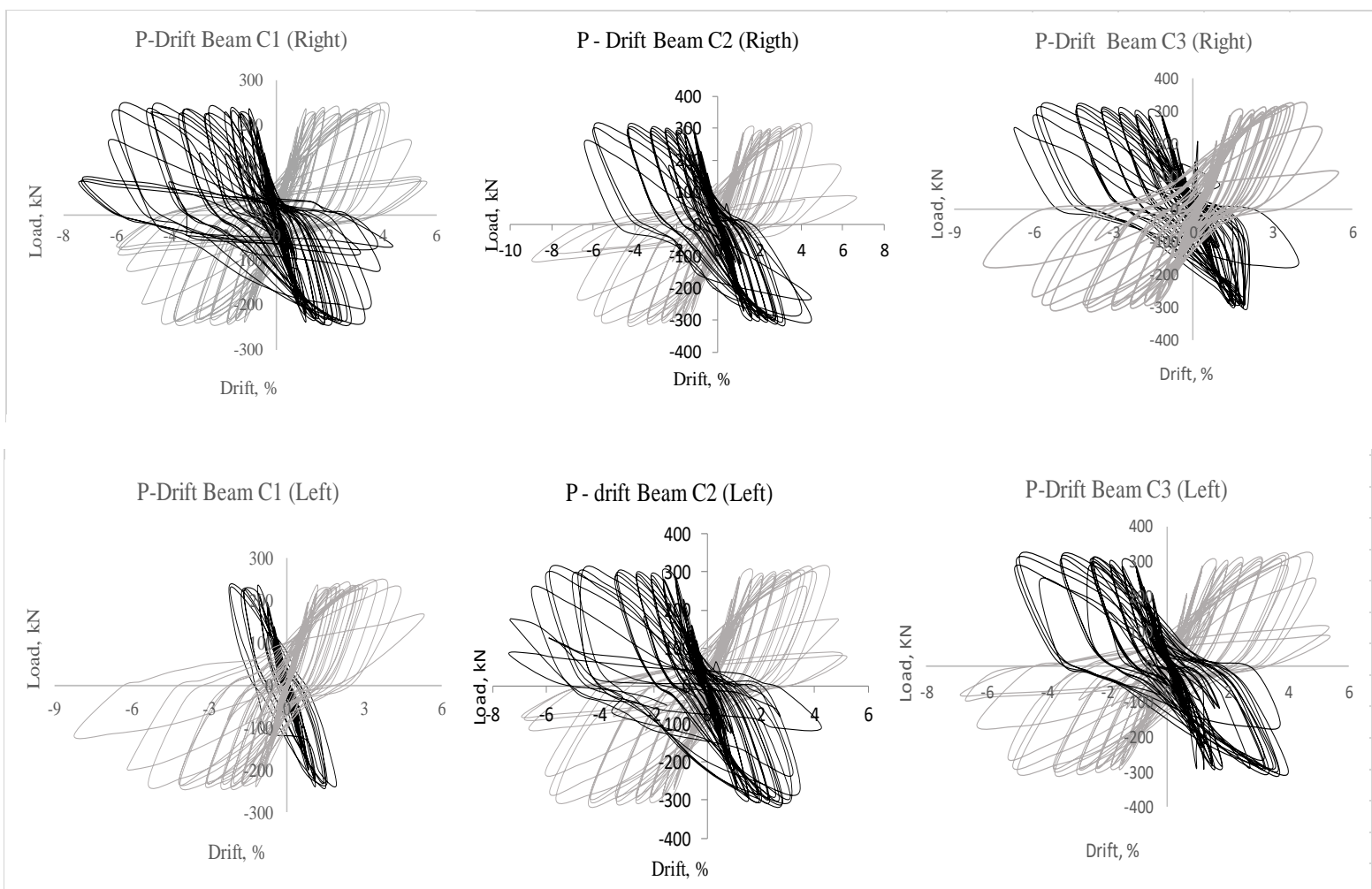

Figure 7. Hysteretic curves of all test beams 


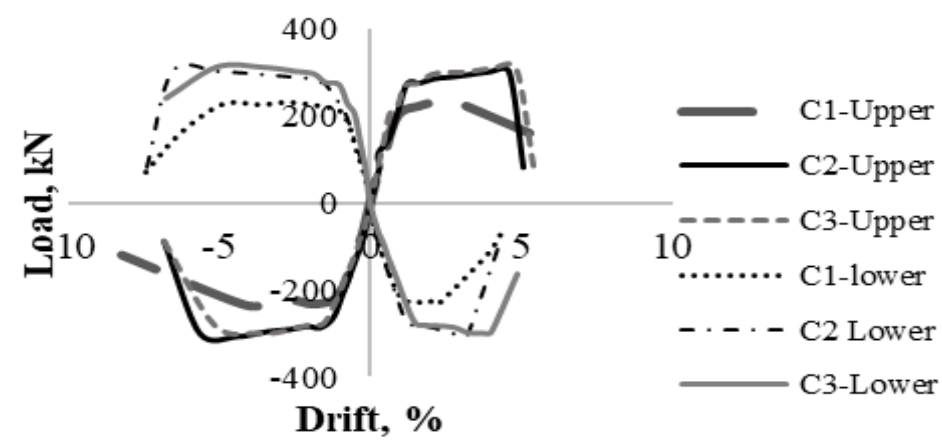

(a)

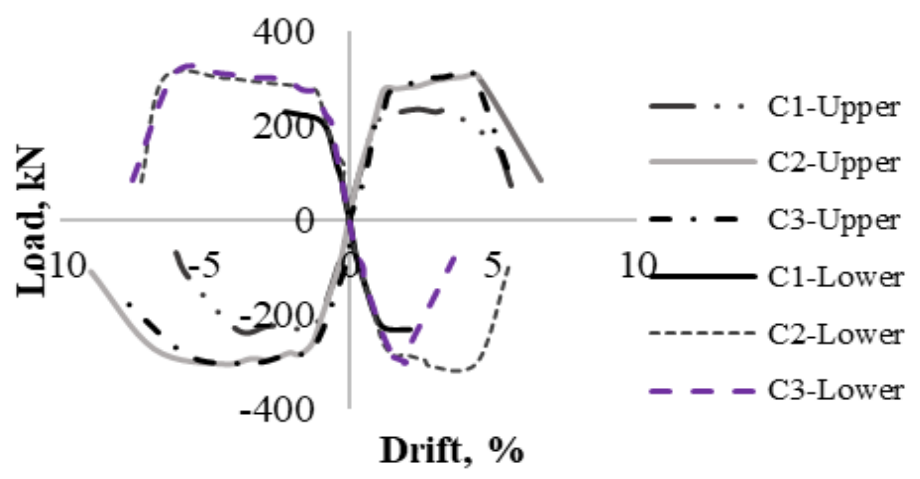

(b)

Figure 8. Backbone curves of all test beams: (a) rigthhand-side beam, (b) lefthand-side beam

Figure 8 shows the backbone comparison of the hysterical curves of each beam. Measurements were made at the right and lefthand sides of the beams. It can be seen that Beams C2 and C3 that used high-strength steel bars could reach longer deformations than Beam $\mathrm{C} 1$. Another parameter that can be used to analyze ductility is the ability of structural members to sustain deformation without significant degradation of stiffness or load and transmit it into energy dissipation. From Figure 8, it can be seen in overall that Beam C2 and $\mathrm{C} 3$ performed longer deformations than Beam $\mathrm{C} 1$. The strengths of Beams $\mathrm{C} 2$ and $\mathrm{C} 3$ are higher than Beam $\mathrm{C} 1$. These findings also confirm that beams with higher-strength steel bars (Grade 80 or $f_{y}$ of $550 \mathrm{MPa}$ ) can still provide sufficient ductility to sustain the reversed cyclic loading.

The post-peak deformations that achieved by Beams $\mathrm{C} 2$ and $\mathrm{C} 3$ are exceeding that of Beam $\mathrm{C} 1$. These two beams even though have experienced large post-peak deformations but they were still able to maintain the loads. It is also shown in Figure 8 that the areas under the hysteretic curves exhibit the ability of the beams to dissipate energy. This parameter can also indicate the ductility of the beams under reversed cyclic loading.

All of the above analysis and discussion shows that further extensive research is still needed to come up with higher-strength steel bars with better mechanical properties that do not only satisfy all the standard and code requirements, but also reliable to be implemented in seismic-resistant concrete structures which are located in highly seismic regions (SDC D, E, and F). 


\section{Conclusions}

Based on the research results that have been elaborated and discussed above, it can be concluded that the beams with higher-strength steel bars can certainly attain higher load capacity than those with normal-strength steel bars. Beam C3 reached the highest $P_{\max }$ of about $311 \mathrm{kN}$, whereas Beam C2 at $P_{\max }$ of about $300 \mathrm{kN}$. In terms of deflection or drift ratio, the beams with higher-strength steel bars experienced larger deflections or drift ratios compared to those of the beam with normal-strength steel bars. All the beams were capable of achieving the drift ratios exceeding 3.5 percent as required by the bulding code. Besides, the beams with higher-strength steel bars did not experience any brittle and abrupt collapse as concerned earlier. These findings recommend the possibility of higher-strength steel bars (Grade 80 or $f_{y}$ of $550 \mathrm{MPa}$ ) to be implemented in the future as a viable option for concrete members particularly beams which are parts of the special moment frames located in highlyseismic zones (SDC D, E,F).

\section{Acknowledgment}

The authors would like to express their sincere gratitude for all the supports and facilities provided by PT. Tunggal Jaya Steel, PT. Bhirawa Steel, and PT. Varia Usaha Beton. All the fundings received to make the research possible is also gratefully acknowledged. The authors also gratefully acknowledge financial support from the Institut Teknologi Sepuluh Nopember for this work, under project scheme of the Publication Writing and IPR Incentive Program (PPHKI).

\section{References}

[1] I G. P. Raka, Tavio, and M. D. Astawa, "State-of-the-art report on partially-prestressed concrete earthquake-resistant building structures for highly-seismic region," Procedia Engineering, Vol. 95, pp. 43-53, 2014.

[2] D.I. Wahjudi, H. Sugihardjo, and Tavio, "Behavior of precast concrete beam-to-column connection with $\mathrm{u}$ - and l-bent bar anchorages placed outside the column panel Experimental study," Procedia Engineering, Vol. 95, pp. 122-131, 2014.

[3] Tavio, "Interactive mechanical model for shear strength of deep beams," Journal of Structural Engineering, Vol. 132, No. 5, pp. 826-829, 2006.

[4] Tavio, and S. Teng, "Effective torsional rigidity of reinforced concrete members," ACI Structural Journal, American Concrete Institute (ACI), Farmington Hills, Michigan, United States, Vol. 101, No. 2, pp. 252-260, 2004.

[5] P. Pudjisuryadi, and Tavio, "Performance of square reinforced concrete columns externally confined by steel angle collars under combined axial and lateral load," Procedia Engineering, Vol. 125, pp. 1043-1049, 2015.

[6] B. Sabariman, A. Soehardjono, Wisnumurti, A. Wibowo, and Tavio, "Stress-strain behavior of steel fiber-reinforced concrete cylinders spirally confined with steel bars," Advances in Civil Engineering, Vol. 2018, pp. 1-8, 2018.

[7] B. Kusuma, and Tavio, "Axial load behavior of concrete columns with welded wire fabrics as transverse reinforcement," Procedia Engineering, Vol. 14, pp. 2039-2047, 2011.

[8] Tavio, and B. Kusuma, "Investigation of stress-strain models for confinement of concrete by welded wire fabric," Procedia Engineering, Vol. 14, pp. 2031-2038, 2011.

[9] J.M. Rautenberg, S. Pujol, H. Tavallali, and A. Lepage, "Cyclic response of concrete columns reinforced with high-strength steel," Paper presented at The 9th U.S. National 
and 10th Canadian Conference on Earthquake Engineering: Reaching Beyond Borders, Earthquake Engineering Research Institute (EERI), Toronto, Ontario, Canada, 2010.

[10] Tavio, and B. Kusuma, "Ductility of confined reinforced concrete columns with welded reinforcement grids," In: Proceedings of the International Conference on Concrete Construction: Excellence in Concrete Construction through Innovation, CRC Press, London, United Kingdom, pp. 339-344, 2008.

[11] Tavio, and B. Kusuma, "Stress-Strain model for high-strength concrete confined by welded wire fabric," Journal of Materials in Civil Engineering, Vol. 21, No. 1, pp. 4045, 2009.

[12] American Concrete Institute, Building Code Requirements for Structural Concrete (ACI 318-19) and Commentary on Building Code Requirements for Structural Concrete (ACI 318R-19), Farmington Hills, Michigan, United States, 2019.

[13] American Concrete Institute, Building Code Requirements for Structural Concrete (ACI 318-14) and Commentary on Building Code Requirements for Structural Concrete (ACI 318R-14), Farmington Hills, Michigan, United States, 2014.

[14] ASTM International, Standard Specification for Deformed and Plain Low-Alloy Steel Bars for Concrete Reinforcement (ASTM A706/A706M-16), West Conshohocken, Pennsylvania, United States, 2016.

[15] ASTM International, Standard Specification for Deformed and Plain, Low-Carbon, Chromium, Steel Bars for Concrete Reinforcement (ASTM A1035/A1035M-20), West Conshohocken, Pennsylvania, United States, 2020.

[16] ASTM International, Standard Specification for Deformed and Plain Carbon-Steel for Concrete Reinforcement (ASTM A615/A615M-20), West Conshohocken, Pennsylvania, United States, 2020.

[17] Badan Standarisasi Indonesia, Persyaratan Beton Struktural untuk Bangunan Gedung dan Penjelasan (SNI 2847:2019), Jakarta, Indonesia, 2019.

[18] R. Anggraini, Tavio, I G.P. Raka, and Agustiar, "Stress-strain relationship of highstrength steel (hss) reinforcing bars," AIP Conference Proceedings, AIP Publishing, Vol. 1964, pp. 020025-1-020025-8, 2018.

[19] Tavio, R. Anggraini, I G.P. Raka, and Agustiar, "Tensile strength/yield strength (ts/ys) ratios of high-strength steel (hss) reinforcing bars," AIP Conference Proceedings, Vol. 1964, pp. 020036-1-020036-8, 2018.

[20] Agustiar, Tavio, I G.P. Raka, and R. Anggraini, "Evaluation of higher-strength steel reinforcing bar elongation for seismic design according to various standard specifications," AIP Conference Proceedings, Vol. 2059, pp. 020033-1-020033-8, 2019.

[21] K.A. Harries, B.M. Shahrooz, A. Soltani, "Flexural cracks widths in concrete girders with high-strength reinforcement," Journal of Bridge Engineering, Vol. 17, No. 5, 2012.

[22] J.Y. Lee, I.J. Choi, and S.W. Kim, "Shear behavior of reinforced concrete beams with high-strength stirrups," ACI Structural Journal, Vol. 108, No. 5, pp. 620-629, 2011.

[23] D.J. Kelly, A. Lepage, C. Mar, J.I. Restrepo, J.C. Sanders, and A.W. Taylor, "Use of high-strength reinforcement for earthquake resistant concrete structures", Paper presented at The 10 $0^{\text {th }}$ U.S. National Conference on Earthquake Engineering: Frontiers of Earthquake Engineering, Earthquake Engineering Research Institute (EERI), Anchorage, Alaska, 2014.

[24] J.M. Rautenberg, S. Pujol, H. Tavallali, and A. Lepage, "Drift capacity of concrete columns reinforced with high-strength steel," ACI Structural Journal, Vol. 110, No. 2, pp. 307-317, 2013. 
[25] American Concrete Institute, ACI ITG-6R-10 Design Guide for the Use of ASTM A1035/A1035M Grade 100 (690) Steel Bars for Structural Concrete, Farmington Hills, Michigan, United States, 2010.

[26] A. Azizinamini, S.S.B Kuska, P. Brungardt, and E. Hatfield, "Seismic behavior of square high-strength concrete columns," ACI Structural Journal, Vol. 91, No. 3, pp. 336-345, 1994.

[27] M. Saatcioglu, Member ASCE, and S.R. Razvi, "High-strength concrete columns with square sections under concentric compression," Journal of Structural Engineering, Vol. 124, No.12, pp. 1438-1447, 1998.

[28] S.R. Razvi, M. Saatcioglu, and Member ASCE, "Confinement model for high-strength concrete,” Journal of Structural Engineering, Vol. 125, No. 3, pp. 281-289, 1999.

[29] Tavio, and B. Kusuma, "Strength and ductility enhancement of reinforced hsc columns confined with high-strength transverse steel," In: Proceeding of the Eleventh East AsiaPacific Conference on Structural Engineering \& Construction (EASEC-11), Taipei International Convention Center, Taipei, Taiwan, pp. 350-351, 2008.

[30] Tavio, and B. Kusuma, "Experimental behavior of concrete columns confined by welded wire fabric as transverse reinforcement under axial compression," $A C I$ Structural Journal, American Concrete Institute (ACI), Farmington Hills, Michigan, United States, Vol. 109, No. 3, pp. 339-348, 2012.

[31] Agustiar, Tavio, I G.P. Raka, and R. Anggraini, "Behavior of concrete columns reinforced and confined by high-strength steel bars," International Journal of Civil Engineering and Technology, Vol. 9, No. 7, pp. 1249-1257, 2018.

[32] S.A. Sheikh, and Y. Li, "Design of FRP confinement for square concrete columns," Engineering Structures, Vol. 29, No. 6, pp. 1074-1083, 2007.

[33] H. Tavallali, A. Lepage, J.M. Rautenberg, and S. Pujol, "Concrete beams reinforced with high-strength steel subjected to displacement reversals," ACI Structural Journal, Vol. 111, No. 5, pp. 1037-1048, 2014.

[34] D.V. To, and J.P. Moehle, "Special moment frames with high-strength reinforcementPart 1: Beams," ACI Structural Journal, Vol. 117, No. 2, pp. 239-252, 2020.

[35] R. Anggraini, Tavio, I G.P. Raka, and Agustiar, "Flexural capacity of concrete beams reinforced with high-strength steel bars under monotonic loading," International Journal of GEOMATE, Vol. 20, No. 77, pp. 173-180, 2021.

[36] American Concrete Institute, Acceptance Criteria for Moment Frames Based on Structural Testing and Commentary (ACI 374.1-05), Farmington Hills, Michigan, United States, 2005. 